\title{
Inhibition of leucocyte motility by drugs used in ulcerative colitis
}

\author{
J M RHODES,* T C B ARTHOLOMEW, AND D P JEWELL \\ From the Department of Medicine, Royal Free Hospital, London
}

SUMMARY The effects on leucocyte motility of sulphasalazine (Salazopyrin) and its metabolites sulphapyridine and 5 amino-salicyclic acid have been compared with those of prednisolone and indomethacin. Sulphasalazine, its active metabolite 5 amino-salicylic acid, and prednisolone are all potent inhibitors of leucocyte motility. Sulphapyridine and indomethacin are non-inhibitory. Inhibition of leucocyte motility may explain why sulphasalazine and 5 amino-salicylic acid are effective in ulcerative colitis while sulphapyridine is not. The lack of effect of indomethacin suggests that this action of sulphasalazine does not involve inhibition of prostaglandin synthesis.

Sulphasalazine is highly effective as maintenance therapy in ulcerative colitis ${ }^{12}$ and may also be effective in Crohn's disease. ${ }^{3}$ It is largely split by the colonic flora into two metabolites, 5 aminosalicylic acid and sulphapyridine. ${ }^{*}$ Sulphasalazine and 5 amino-salicylic acid are therapeutically effective when given as enemata, while sulphapyridine is not. ${ }^{5}$ It has therefore been suggested that the salicylate component of sulphasalazine might be working by inhibiting prostaglandin synthesis. Certainly, sulphasalazine has been shown to do this, both in vitro" i and in vivo." "However, indomethacin, an even more potent inhibitor of prostaglandin synthetase, and salicylates other than 5 amino-salicylic acid, have been tried in ulcerative colitis without success. ${ }^{10-12}$

The acute inflammatory mucosal infiltrate of ulcerative colitis can be compared with that found in an experimental Arthus reaction. Neutrophil depletion $^{131^{14}}$ and drug-induced inhibition of neutrophil chemotaxis ${ }^{1.5}$ have both been shown to prevent injury in experimental Arthus reactions. Prednisolone is a potent inhibitor of neutrophil chemotaxis and it seems possible that in ulcerative colitis the beneficial effects of both corticosteroids and sulphasalazine may be due, at least in part, to suppression of leucocyte motility.

\footnotetext{
*Address for correspondence: Dr J M Rhodes, Department of Medicine, Queen Elizabeth Medical Centre, Edgbaston, Birmingham. †Present address: John Radcliffe Hospital, Headington, Oxford. Received for publication 28 January 1981
}

\section{Methods}

C E L L IS O L A T I O N

Twenty millilitres of venous blood (heparin $5 \mathrm{u} /$ $\mathrm{ml}$ ) were obtained from healthy subjects, sedimented with Dextran 110 in $0.9 \%$ sodium chloride, and the supernatant centrifuged on a FicollHypaque gradient. ${ }^{16}$

Neutrophils were obtained from the cell pellet (purity $>95 \%$ ) and mononuclear cells from the interface (monocytes $>60 \%$ by peroxidase staining). The cells were suspended in Gey's medium containing $1 \mathrm{mg} / \mathrm{ml}$ pure human serum albumin (Behringwerke) and corrected to a final concentration of $2 \times 10^{6}$ cells $/ \mathrm{ml}$ using an improved Neubauer chamber (Weber).

D R U G S

Pure preparations of prednisolone sodium phosphate, sulphasalazine, 5 amino-salicylic acid, sulphapyridine, and indomethacin were studied. Drug stock solutions in Gey's medium were made on the morning of test and corrected as necessary to pH7.2 using $0.05 \mathrm{M}$ Tris/ $\mathrm{HCl}$ buffer. The drug under test was added to both cell suspension and chemotactant so as to give the same final drug concentration above and below the filter. Seven serial dilutions of each drug were studied.

CHEMOTAXIS A N D R A N DOM

MOT I L I T Y A S SA Y S

The modified Boyden chamber assay described by

Wilkinson $^{17}$ was used. $3 \mu$ pore diameter filters 
(Millipore) were used for neutrophil chemotaxis and $8 \mu$ pore diameter for monocyte chemotaxis. Chemotaxis was directed towards casein $4 \mathrm{mg} / \mathrm{ml}$ (Sigma). Random motility was assayed in the presence of purified human serum albumin (Behringwerke) $1 \mathrm{mg} / \mathrm{ml}$. Cells from the same population suspended in the presence and absence of test drug were tested simultaneously. Neutrophil chemotaxis and random motility were allowed to proceed for $\mathbf{4 0}$ minutes and 75 minutes respectively, monocyte chemotaxis, and random motility for two hours. They took place in a humidified incubator containing $5 \% \mathrm{CO}_{2}$ at $37^{\circ} \mathrm{C}$. Each filter was then fixed, stained, and mounted and the distance moved by the leading cell front was measured in five randomly selected high power fields using the micrometer focusing adjustment of a Leitz SM microscope. Each assay was run in triplicate so that each result represents the mean of 15 observations.

Results for drug inhibition of both random motility and chemotaxis were expressed as:

\section{Percentage inhibition $=100-$ ( $\frac{\text { distance }(\mu) \text { moved by cells in presence of drug }}{\text { distance }(\mu) \text { moved by cells in absence of drug }}$}

R E V E R S I B I L I T Y

Reversibility of the drug effects was assessed in a separate experiment by incubating aliquots of leucocytes in drug solutions for one hour at $37^{\circ} \mathrm{C}$ before assay. One half of each aliquot was then washed three times in Gey's medium before assay of random motility, while the other half was kept in the drug solution during the assay.

V I A B I L I T Y

Cell viability was measured after incubation for one hour in the test drug solution. It was tested by both trypan blue dye exclusion and by measurement of membrane chloride gradient.

Membrane chloride gradient was measured using the method of Baur et al. ${ }^{1 \times}$ Three $0.5 \mathrm{ml}$ aliquots of each cell suspension were taken. The first was incubated for 10 minutes at $37^{\circ} \mathrm{C}$ with $2.5 \mu \mathrm{Ci}{ }^{3} \mathrm{H}_{2} \mathrm{O} / \mathrm{ml}$ and the cells then separated from the supernatant by centrifugal filtration through silicon oil. Both the cell pellet and supernatant were then counted on a Phillips PW4530 scintillation counter after addition of $10 \mathrm{ml}$ NE 260 scintillation cocktail (Nuclear Enterprises Ltd). The intracellular water volume of the cell pellet was then calculated. The second aliquot was incubated for 10 minutes at $37^{\circ} \mathrm{C}$ with $0.5 \mu \mathrm{Ci}^{14} \mathrm{C}$ dextran $/ \mathrm{ml}$ and the cell pellet separated and counted as before. The adherent water was then calculated. The third aliquot was incubated for 10 minutes at $37^{\circ} \mathrm{C}$ with $0.5 \mu \mathrm{Ci}^{36} \mathrm{Cl}^{-} / \mathrm{ml}$ at $37^{\circ} \mathrm{C}$ and the cell pellet again separated and counted. The intracellular chloride concentration was then calculated making allowance for the chloride content of the adherent water.

Results were then expressed as: percentage change in membrane chloride gradient $=100-$
chloride gradient of cells incubated without drug
$\times 100) \%$

\section{Results}

The distances moved by control leucocytes in the absence of test drug were as follows:

Neutrophil random motility $46.4 \mu \pm 4.9$ (standard error), neutrophil chemotaxis $78 \cdot 4 \mu \pm 10 \cdot 0$, monocyte random motility $45 \cdot 0 \mu \pm 4 \cdot 6$, monocyte chemotaxis $122 \cdot 4 \mu \pm 8 \cdot 7$.

Dose response curves were plotted for the percentage inhibition of leucocyte motility caused by serial dilutions of each test drug (Figs. 1 and 2). By interpolation from these curves the drug concentrations required for $50 \%$ inhibition of neutrophil chemotaxis were sulphasalazine $2.51 \mathrm{mmol} / 1$ $(1.00 \mathrm{mg} / \mathrm{ml}), 5$ amino-salicylic acid $32.7 \mathrm{mmol} / 1$ $(5.01 \mathrm{mg} / \mathrm{ml})$, and prednisolone $1.45 \mathrm{mmol} / 1$ $(0.70 \mathrm{mg} / \mathrm{ml})$. Sulphapyridine caused no significant inhibition at $40 \mathrm{mmol} / 1(10.0 \mathrm{mg} / \mathrm{ml})$, a concentration considerably greater than that which may occur in the colon of patients treated with sulphasalazine. ${ }^{19}$ Indomethacin caused no significant inhibition at a concentration $0.028 \mathrm{mmol} / 1$ $(0.01 \mathrm{mg} / \mathrm{ml})$ greater than that required to cause $100 \%$ inhibition of prostaglandin synthesis. ${ }^{20}$ Higher concentrations of indomethacin caused cell lysis.

Similar drug concentrations produced inhibition of monocyte chemotaxis and inhibition of random motility of both neutrophils and monocytes. Again, both sulphapyridine $(40 \mathrm{mmol} / 1 ; 10.0 \mathrm{mg} /$ $\mathrm{ml})$ and indomethacin $(0.028 \mathrm{mmol} / \mathrm{l} ; 0.01 \mathrm{mg} / \mathrm{ml})$ had no effect (Table 1).

The above experiments were performed on leucocytes from a single healthy subject. To exclude an idiosyncratic response of these leucocytes, drug 


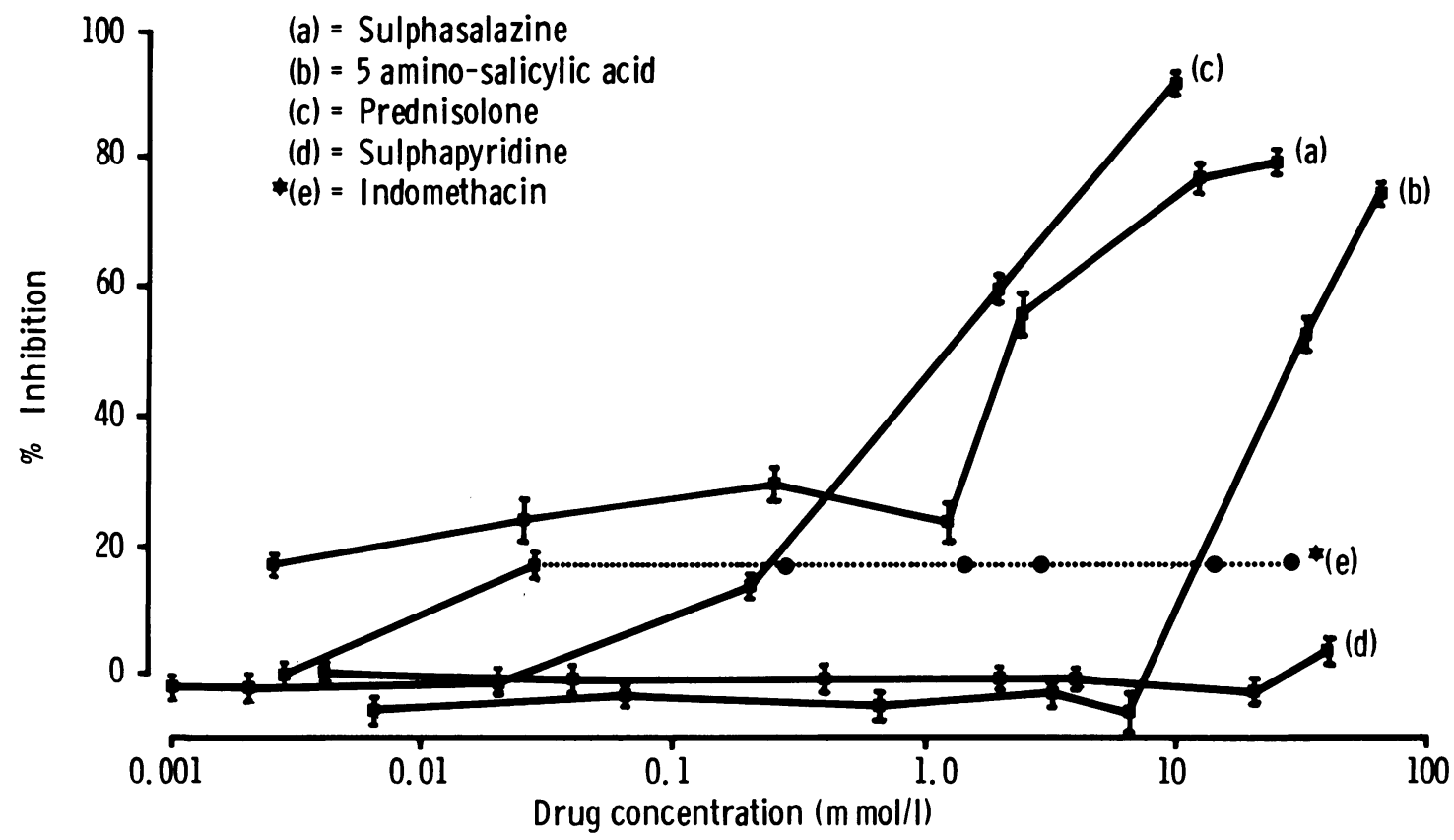

Fig. 1 Drug inhibition of neutrophil chemotaxis. ${ }^{*}$ Cell lysis occurred at indomethacin concentrations of $0.28 \mathrm{mmol} / \mathrm{l}$ and above.

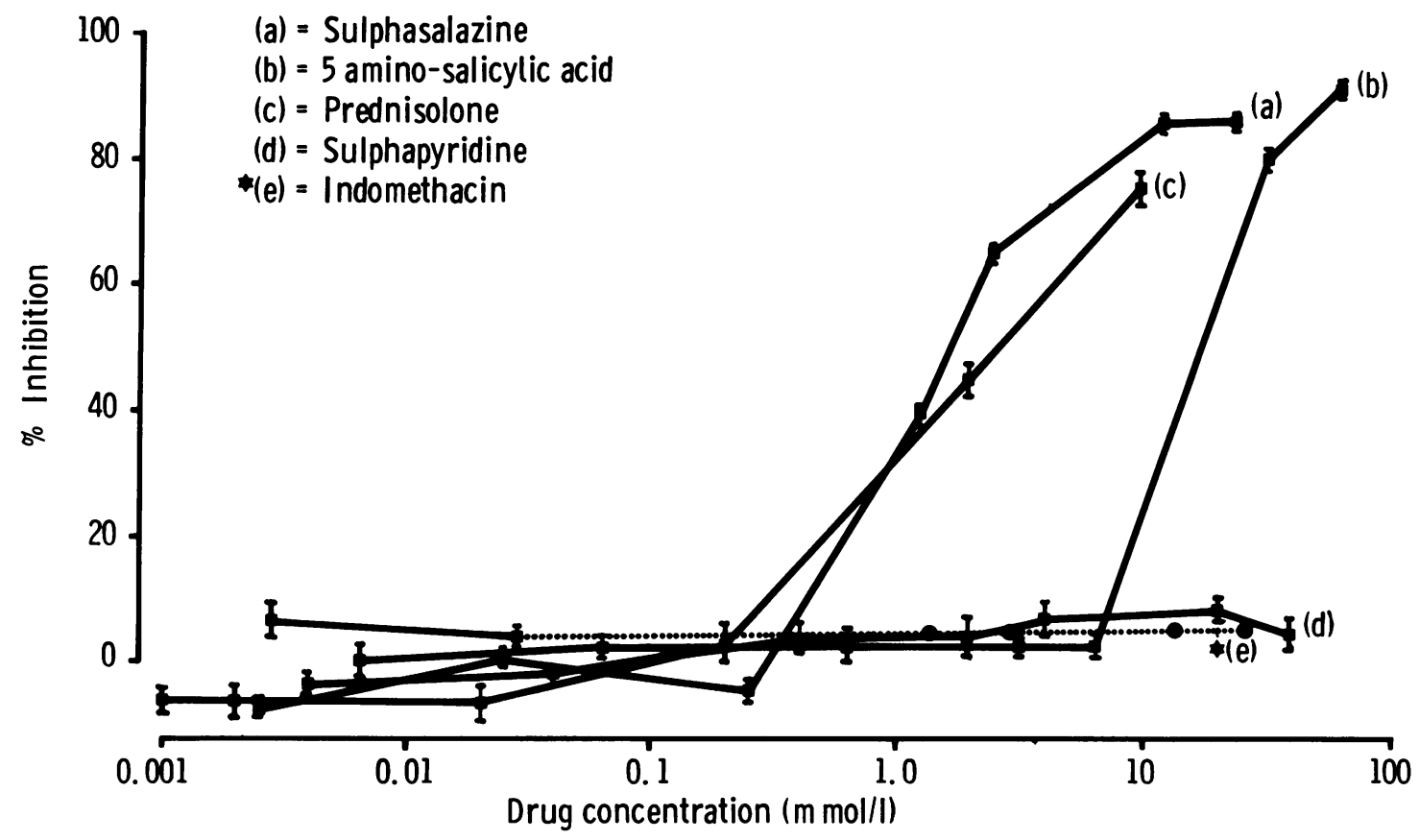

Fig. 2 Drug inhibition of neutrophil random motility. ${ }^{*}$ Cell lysis occurred at indomethacin concentrations of $0.28 \mathrm{mmol} / \mathrm{l}$ and above. 
Table 1 Drug concentrations causing 50\% inhibition of leucocyte chemotaxis and random motility

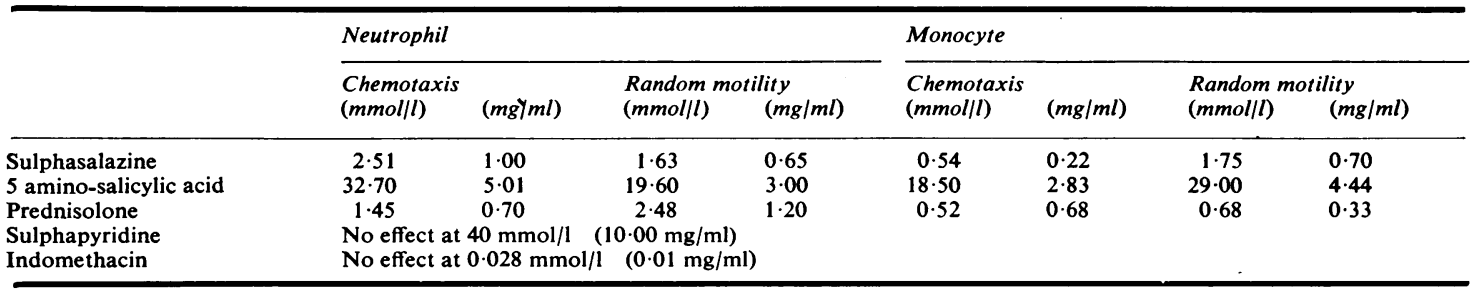

concentrations similar to those required for $50 \%$ inhibition of random motility were then tested on leucocytes obtained from another four healthy subjects (two male and two female). Indomethacin was tested again at $0.028 \mathrm{mmol} / 1(0.01 \mathrm{mg} / \mathrm{ml})$ and sulphapyridine at $4 \mathrm{mmol} / 1(1.0 \mathrm{mg} / \mathrm{ml})$. Sulphasalazine $1.6 \mathrm{mmol} / \mathrm{l}(0.64 \mathrm{mg} / \mathrm{ml})$ caused a mean inhibition of random neutrophil motility of $67 \%$ (range 58 to $78 \%$ ), 5 amino-salicyclic acid $(19.6 \mathrm{mmol} / \mathrm{l} ; 3 \mathrm{mg} / \mathrm{ml})$ caused $94 \%$ inhibition (range 92 to $96 \%$ ), prednisolone $2 \mathrm{mmol} / 1(0.97$ $\mathrm{mg} / \mathrm{ml}$ ) caused $50 \%$ inhibition (range 39 to $65 \%$ ) sulphapyridine $(4 \mathrm{mmol} / 1 ; 1.0 \mathrm{mg} / \mathrm{ml})$ caused only $1 \%$ inhibition (range -4 to $11 \%$ ) and indomethacin $(0.028 \mathrm{mmol} / 1 ; 0.01 \mathrm{mg} / \mathrm{ml}$ ) minus $8 \%$ (range -22 to 5) (Table 2).

To establish whether the drugs tested might simply be having a direct toxic effect, neutrophils incubated for one hour in the same drug concentrations were assessed for viability. Trypan

Table 2 Inhibition of random motility of neutrophils from four healthy subjects

\begin{tabular}{|c|c|c|c|c|}
\hline & \multicolumn{2}{|c|}{ Drug concentration } & \multicolumn{2}{|c|}{$\%$ Inhibition } \\
\hline & $(\mathrm{mmol} / \mathrm{l})$ & $(m g / m l)$ & Mean & Range \\
\hline Sulphasalazine & $1 \cdot 6$ & 0.64 & 67 & $58-78$ \\
\hline 5 amino-salicylic acid & $19 \cdot 6$ & $3 \cdot 0$ & 94 & $92-96$ \\
\hline Sulphapyridine & $4 \cdot 0$ & $1 \cdot 0$ & 1 & $-4-11$ \\
\hline Prednisolone & $2 \cdot 0$ & 0.97 & 50 & $39-65$ \\
\hline Indomethacin & 0.028 & 0.01 & -8 & $-22-5$ \\
\hline
\end{tabular}

Table 3 Effect of drugs tested on neutrophil membrane chloride gradient

\begin{tabular}{lcl}
\hline & $\begin{array}{l}\text { Drug concentration } \\
\text { tested } \\
(\text { mmol/l) }\end{array}$ & $\begin{array}{l}\text { Change in } \\
\text { chloride gradient } \\
\text { vs control cells } \\
(\%)\end{array}$ \\
\hline Prednisolone & 2.0 & +7.0 \\
Sulphasalazine & 1.6 & +10.7 \\
5 amino-salicylic acid & 19.6 & -141.6 \\
Sulphapyridine & 4.0 & -18.3 \\
Indomethacin & 0.028 & +10.7 \\
\hline
\end{tabular}

blue dye exclusion was greater than $95 \%$ in each case. Membrane chloride gradient in the presence of all test drugs except 5 amino-salicylic acid was within $18 \%$ of the chloride gradient of the control cells incubated in Gey's medium (Table 3). The cells incubated in 5 amino-salicyclic acid showed an apparent change in chloride gradient of $-142 \%$. This was probably partly an artefact caused by some of the 5 amino-salicylic acid precipitating out, but some damage to the cell membranes cannot be excluded.

Another experiment was performed to determine whether the inhibitory effects of the drugs studied were reversible. Aliquots of neutrophils were incubated for one hour at $37^{\circ} \mathrm{C}$ in the presence of sulphasalazine $1.6 \mathrm{mmol} / 1(0.64 \mathrm{mg} / \mathrm{ml})$, 5 amino-salicylic acid $19.6 \mathrm{mmol} / 1(3 \mathrm{mg} / \mathrm{ml})$, and prednisolone $2 \mathrm{mmol} / \mathrm{l}(0.97 \mathrm{mg} / \mathrm{ml})$. An additional aliquot was incubated in Gey's medium as control. After incubation half of each aliquot was washed three times in Gey's medium and all aliquots were then set up in the random motility assay. As expected, the unwashed cells showed inhibition of random motility by prednisolone $2 \mathrm{mmol} / \mathrm{l}(81 \%$ inhibition \pm SE $2 \cdot 0)$, sulphasalazine $1.6 \mathrm{mmol} / 1(91 \%$ inhibition $\pm \mathrm{SE} 1 \cdot 3)$, and 5 amino-salicylic acid $19.6 \mathrm{mmol} / 1$ (95\% inhibition \pm SE 0.98). Cells that had been washed after incubation for one hour in 5 amino-salicylic acid regained normal motility $(0 \%$ inhibition \pm SE 1.55$)$ as did those that had been washed after incubation in prednisolone $(20 \%$ inhibition \pm SE $1 \cdot 29)$. However, the motility of cells that had been washed after incubation in sulphasalazine remained inhibited $(88 \%$ inhibition \pm SE 0.93$)$.

\section{Discussion}

Sulphasalazine, 5 amino-salicylic acid, and prednisolone are shown to inhibit leucocyte random motility and chemotaxis. Their action is not cell specific, for both neutrophils and monocytes are similarly affected. The effect of 5 amino-salicylic acid, like that of prednisolone, is reversed by 
washing the cells, suggesting that it is very unlikely to be due to a direct toxic effect on the cells. The effect of sulphasalazine is not reversible, so that it may result partly from a toxic effect, although cell membrane function is not apparently impaired. In the assay system used here chemotaxis (directional movement of cells) cannot be clearly distinguished from chemokinesis (altered speed of movement of cells), although casein, the attractant used, is known to cause true chemotaxis. ${ }^{21}$ However, similar drug concentrations are required to inhibit both random motility and chemotaxis, which suggests that the effect of the drugs on chemotaxing cells is due to reduced speed of cell movement rather than any specific effect on directional motility.

The inhibition of leucocyte motility by sulphasalazine and 5 amino-salicylic acid, but not by sulphapyridine, corresponds well with the relative therapeutic effects of these compounds. These findings differ from those recently reported by Molin and Stendahl ${ }^{22}$ who found that sulphasalazine and sulphapyridine inhibited leucocyte migration under agarose, while 5 amino-salicylic acid did not. This discrepancy may perhaps be due to their use of the agarose plate assay system, which is much less affected by changes in leucocyte deformability and therefore arguably less analogous to the situation in vivo. There are also problems with the use of 5 amino-salicylic acid in in-vitro cell culture systems, as it is unstable at physiological $\mathrm{pH}$ and the longer incubation period required in the agarose plate assay may lead to greater degradation of the drug. Furthermore, 5 amino-salicylic acid is not very soluble and tended to precipitate out during the filter chamber assay reported here. The true concentration of drug in solution may therefore be considerably lower than that quoted by Molin and Stendahl and this may also account for the fact that sulphasalazine appears in our study to be a stronger inhibitor of motility than 5 amino-salicylic acid. Precipitation of 5 amino-salicyclic acid during the filter assay did not in itself appear to cause any significant mechanical obstruction to the leucocytes, as, even at inhibitory drug concentrations, a large proportion of the cells had migrated beyond the lowest observable drug precipitates.

The concentrations of sulphasalazine and 5 amino-salicylic acid required for inhibition of leucocyte motility are many times greater than those which are found therapeutically in plasma but are similar to those found in the faeces of treated patients. ${ }^{19}$ Previous work suggests that the effect of sulphasalazine is largely due to the high drug levels that occur in the colon. ${ }^{4}$ It therefore seems quite likely that inhibition of leucocyte motility will occur locally in the colonic mucosa of patients receiving the drug. Molin and Stendahl also reported that sulphasalazine causes reduced neutrophil phagocytosis and superoxide production, ${ }^{22}$ so that its therapeutic action may be the result of suppression of several aspects of neutrophil function. Prednisolone also is only inhibitory in vitro at much greater concentrations than those occurring therapeutically in vivo, ${ }^{23}$ although the concentrations which occur locally in patients receiving prednisolone enemata may well be inhibitory.

This study shows that indomethacin has no effect on leucocyte motility at concentrations greater than those required completely to inhibit prostaglandin synthesis and this has also been reported by others. ${ }^{24}{ }^{2 \pi}$ This implies that the inhibition of leucocyte motility caused by sulphasalazine is mediated by some mechanism other than inhibition of prostaglandin synthesis. As the two published trials of indomethacin in ulcerative colitis have been negative ${ }^{10} 11$ it also seems likely that the therapeutic action of sulphasalazine is independent of prostaglandin synthesis inhibition. If this is so, then inhibition of leucocyte motility may well be its mechanism of action.

We should like to thank Pharmacia (UK) and Merck, Sharp and Dohme (UK) for supplying pure drug preparations, JMR was supported by the Stanley Thomas Johnson Foundation.

\section{References}

${ }^{1}$ Misiewicz JJ, Lennard-Jones JE, Connell AM, Baron JH, Avery-Jones F. Controlled trial of sulphasalazine in maintenance therapy of ulcerative colitis. Lancet 1965 ; 1:185-8.

2Dissanayake AS, Truelove SC. A controlled therapeutic trial of long-term maintenance treatment of ulcerative colitis with sulphasalazine. Gut 1973; 14: 923-6.

'Summers RW, Switz DM, Sessions JT, Becktel JM, Best WR, Kern F, Singleton JW. National cooperative Crohn's disease study: results of drug treatment. Gastroenterology 1979; 77:847-69.

${ }^{4}$ Peppercorn MA, Goldman P. The role of intestinal bacteria in the metabolism of salicylazo-sulphapyridine. J Pharmacol Exp Ther 1972; 181:555-62.

"Azad Khan AK, Piris J, Truelove SC. An experiment to determine the active therapeutic moiety of sulphasalazine. Lancet 1977; 2:892-5.

'Gould SR. Prostaglandins, ulcerative colitis and sulphasalazine. Lancet 1975; 2:988.

${ }^{7}$ Hoult JR, Moore PK. Sulphasalazine is a potent inhibitor of prostaglandin 15-hydroxydehydrogenase: 
possible basis for therapeutic action in ulcerative colitis. Br J Pharmacol 1978; 64:6-8.

'Sharon P, Ligumsky M, Rachmilewitz D, Zor U. Role of prostaglandins in ulcerative colitis. Enhanced production during active disease and inhibition by sulphasalazine. Gastroenterology 1978; 75:638-40.

'Smith PR, Dawson DJ, Swan CHJ. Prostaglandin synthetase activity in acute ulcerative colitis: effects of treatment with sulphasalazine, codeine phosphate and prednisolone. Gut 1979; 20:802-5.

"Campieri M, Lanfranchi GA, Bazzocchi G, et al. Salicylate other than 5 amino-salicylic acid ineffective in ulcerative colitis. Lancet 1978; 2:993.

${ }^{11 G i l a t ~ T, ~ R a t a n ~ J, ~ R o s e n ~ P, ~ P e l e d ~ Y . ~ P r o s t a g l a n d i n s ~}$ and ulcerative colitis. Gastroenterology 1979; 76: 1083.

${ }^{12}$ Campieri M, Lanfranchi GA, Bazzocchi G, Brignola C, Benatti A, Boccia S, Labo G. Prostaglandins, indomethacin and ulcerative colitis. Gastroenterology 1980; 78:193.

1:DeShazo CV, Henson PM, Cochrane CG. Acute immunologic arthritis in rabbits. J Clin Invest 1971; 51:50-7.

${ }^{14}$ DeShazo CV, McGrade MT, Henson PM, Cochrane CG. The effect of complement depletion on neutrophil migration in acute immunologic arthritis. $J$ Immunol 1972; 108:1414-9.

${ }^{15}$ Ward PA. The chemosuppression of chemotaxis. $J$ Exp Med 1966; 124:209-26.

1'Boyum A. Isolation of mononuclear cells and granu- locytes from human peripheral blood. Scand $J$ Clin Invest 1968; 21: Suppl 97:77-89.

${ }_{17}$ Wilkinson PC. Chemotaxis and inflammation. Edinburgh: Churchill Livingstone, 1974; 170-2.

${ }^{18}$ Baur H, Kasperek S, Pfaff E. Criteria of viability of isolated liver cells. Hoppe-Seyler's Z Physiol Chem 1975; 356:827-38.

1 'Peppercorn MA, Goldman P. Distribution studies of salicylazosulfapyridine and its metabolites. Gastroenterology 1973; 64:240-5.

${ }^{20}$ Vane JR. Inhibition of prostaglandin synthesis as a mechanism of action for aspirin-like drugs. Nature New Biol 1971; 231:232-5.

${ }^{21}$ Wilkinson PC. Characterization of the chemotactic activity of casein for neutrophil leucocytes and macrophages. Experientia 1972; 28:1051-2.

${ }^{22}$ Molin L, Stendahl $O$. The effect of sulfasalazine and its active components on human polymorphonuclear leukocyte function in relation to ulcerative colitis. Acta Med Scand 1979; 206:451-7.

2:Powell-Tuck J, Lennard-Jones JE, May CS, Wilson CG, Paterson JW. Plasma prednisolone levels after administration of prednisolone-21-phosphate as a retention enema in colitis. Br Med J 1976; 1:193-5.

2."Walker JR, Smith MJH, Ford-Hutchison AW. Antiinflammatory drugs, prostaglandins and leukocyte migration. Agents Actions 1976; 6: 602-6.

2:Palmer RMJ, Weatherall M. The effect of some anti-inflammatory and anti-malarial drugs on the migration of horse leucocytes in vitro. Br J Pharmacol 1977; 59:472. 